\title{
Assessment of Ricinus communis (Castor Oil) Seed as Potential Protein Source in Weanling Diet Formulations
}

\author{
Ezim Ogechukwu Ebere ${ }^{1, \text { *, Nkwonta Chikere Godwin }}{ }^{2}$ \\ ${ }^{1}$ Department of Biochemistry, University of Port Harcourt, Port Harcourt, Nigeria \\ ${ }^{2}$ Department of Biochemistry, University of Nigeria, Nsukka, Nigeria
}

Email address:

ogechukwu.okafor@uniport.edu.ng (E. O. Ebere)

*Corresponding author

\section{To cite this article:}

Ezim Ogechukwu Ebere, Nkwonta Chikere Godwin. Assessment of Ricinus communis (Castor Oil) Seed as Potential Protein Source in Weanling Diet Formulations. American Journal of BioScience. Vol. 9, No. 2, 2021, pp. 42-46. doi: 10.11648/j.ajbio.20210902.12

Received: March 3, 2021; Accepted: March 19, 2021; Published: March 30, 2021

\begin{abstract}
Protein-rich weanling food products, particularly those from animal sources, are not very accessible and affordable in several developing nations in Africa. Most women resort primarily to the use of only carbohydrate-based food such as cornstarch, to wean their toddlers from breast-feeding. This has led to several children getting affected by protein energy malnutrition and other associated conditions. The need to develop plant-based protein-rich weanling diets is therefore essential to ensure a balance in nutrient intake of toddlers. Growth and maintenance studies using Ricinus communis seed-diet formulations were investigated in wistar rats, to evaluate it's potential as weanling diet. The diets were formulated using AIN 93G methods for laboratory rats during their growth, pregnancy and lactating periods. Thirty weanling male albino rats (40$60 \mathrm{~g}$ ) were utilized in this study, they were divided into five groups of six rats each based on sample treatment respectively. The groups includes; (CAS) casein diet, (BRC) boiled $R$. communis diet, (FRC) fermented $R$. communis diet, (FRC $+\mathrm{C})$ fermented $R$. communis plus charcoal diet, and (NFD) nitrogen free diet. The rats were housed in individual metabolic cages equipped to separate faeces and urine. The growth study lasted for 21 days followed by a 7 days maintenance period. The proximate composition showed that $R$. communis seeds is high in protein (33.25\%) and fat (37.70\%). Boiling and fermentation treatments decreased the protein (23.13 and 20.37\%) and fat (24.5 and 21.0\%) contents, respectively. Sample-based diets were least consumed by the rats, which showed retarded growth as well, compared to CAS control and NFD diet groups. The nitrogen balanced studies showed that over $80 \%$ of the nitrogen consumed from the test diet were absorbed and retained, suggesting high utilization of the seed nitrogen.
\end{abstract}

Keywords: Proximate Composition, Ricinus communis, Protein Quality, Weanling Diet

\section{Introduction}

Plant materials, like the legumes, oil seeds and cereals form an important source of calories and protein for developing countries. The growth and maintenance needs of both children and adult can be achieved through eating of diet that are balanced especially with protein [1]. Protein is very essential in biochemical, biophysical and physiological processes [2].

It has been ascertained that the presence of some antinutrients, low palatability, digestibility and processing techniques reduces the utilization of these plant nutrients [3]. Different detoxification/processing techniques have been employed in order to optimize the utilization of these plant foods. The efficacy of the adopted processing technique depends on the nature and properties of the antinutrients present [4].

Many processing methods have been shown to improve the nutritive value of plant foods for human nutrition [5]. Moderate heat treatment has been reported to improve the digestibility of plant proteins and inactivate several enzymes such as proteases, lipases, lipoxygenases, amylases, and other oxidative hydrolytic enzymes without developing toxic derivatives [5].

The castor oil plant $R$. communis, belongs to the plant family Euphorbiaceae.. The plant has been cultivated for centuries in some countries for the oil produced by its seed. 
Among the vegetable oils, castor oil is distinctive because of its high level of ricinoleic acid (over 85\%) [6].

Castor oil has been in use for centuries for its antimicrobial and anti-bacteria properties. In Nigeria, It is mainly processed by fermentation to eliminate the ricin toxin. The fermented product commonly known as "ogiri" is utilized as food condiment in preparation of cocoyam based soup in eastern part of Nigeria.

This research is an attempt to explore the potentials of an under-utilized plant food as a source of protein.

As laboratory animals were intended for use in this study, approval was obtained from the ethics committee on the use and care of experimental animals of the Faculty of Biological Sciences, University of Nigeria Nsukka.

\section{Material and Method}

\subsection{Sample Preparation}

Boiled sample (BRC). The seeds were par-boiled for $30 \mathrm{~min}$ in a metal pot on an electric cooker. After 30 minutes, the water was drained and the seeds were wrapped in fresh plantain leaf and boiled properly in water in a ratio of 1:3 $(\mathrm{W} / \mathrm{V})$. The seed was boiled until the water was completely absorbed. The boiled sample was dried in an electric oven at $50^{\circ} \mathrm{C}$, ground and stored in afreezer bag at $4^{\circ} \mathrm{C}$.

Fermented sample (FRC). The seed were boiled usingsame procedure as BRC. However after boiling, it was covered in dried pot, allowed to ferment for four days and dried at $50^{\circ} \mathrm{C}$, ground and stored in freezer bag at $4^{\circ} \mathrm{C}$.

\subsection{Diet Formulation}

The diets were formulated using AIN 93G method for laboratory rats during their growth, pregnancy and lactating periods [7]. Casein, boiled $R$. communis (BRC), fermented $R$. communis (FRC) were sources of protein.

The dried ingredients for each diet were weighed into a bowl and mixed manually. An appropriate amount of oil was added and mixed thoroughly with the other ingredients, to a smooth texture by hand, water was added in small quantity at a time until a homogenous mixture was obtained and pelleted manually.

Table 1. Diet composition ( $\mathrm{g} / \mathrm{kg}$ diet).

\begin{tabular}{|c|c|c|c|c|c|}
\hline Diet Ingredient & CAS & BRC & FRC & , FRC+C & NFD \\
\hline CAS & 114.30 & - & - & - & - \\
\hline $\mathrm{BRC}$ & - & 439.06 & - & - & - \\
\hline FRC & - & - & 490.99 & 490.99 & - \\
\hline Corn starch & 206.74 & 206.74 & 165.20 & 165.20 & 557.99 \\
\hline Dextrinised corn starch & 132.00 & 132.00 & 132.00 & 132.00 & 132.00 \\
\hline Sucrose & 116.64 & 51.69 & 41.30 & 41.30 & 139.50 \\
\hline Soy bean oil & 70.00 & 70.00 & 70.00 & 70.00 & 70.00 \\
\hline Mineral mix & 35.00 & 35.00 & 35.00 & 35.00 & 35.00 \\
\hline Vitamin mix & 10.00 & 10.00 & 10.00 & 10.00 & 10.00 \\
\hline L-cystine & 3.00 & 3.00 & 3.00 & 3.00 & 3.00 \\
\hline Choline bitartrate & 2.50 & 2.50 & 2.50 & 2.50 & 2.50 \\
\hline $\mathrm{TBH}$ & 0.014 & 0.014 & 0.014 & 0.014 & 0.014 \\
\hline Charcoal & - & - & - & 16.00 & - \\
\hline
\end{tabular}

CAS - Casein, TBH - Tetrabutyl hydroquinone, AIN - American Institute of Nutrition

\subsection{Proximate analysis}

Percentage concentrations of protein, lipid, crude fibre, moisture and ash of unprocessed (URC), boiled (BRC), fermented (FRC) $R$. communis were determined using the standard method of the Association of Official Analytical Chemist AOAC methods [8]. The crude protein content was calculated by multiplying the organic nitrogen content by a factor of 6.25 [9], while total carbohydrate content was calculated by subtracting the sum of other fraction from 100 .

\subsection{Experimental Design}

Thirty weanling male albino rats $(40-60 \mathrm{~g})$ were supplied by the Veterinary Department of the University of Nigeria Nsukka. The rats were divided into five groups of six rats based on sample treatment respectively. The groups included; casein diet (CAS) boiled R. communis (BRC) diet, fermented
(FRC) diet, fermented Ricinus communis plus charcoal $(\mathrm{FRC}+\mathrm{C})$ diet, and nitrogen free (NFD) diet groups. The rats were housed in individual metabolic cages equipped to separate faeces and urine. After a six-day acclimation period, the rats were weighed prior to access to their respective diets. Fifteen $(15 \mathrm{~g})$ of casein and test diets were fed to the rats daily for a 21 day growth period. Daily food intakes were recorded and weight gain was measured on weekly intervals. The rats in NFD group were fed normal rat chow during the growth studies and NFD diet for maintenance studies. On day 21 and 28 after weight measurement, carmine red was added to each diet to mark the beginning and end of nitrogen balance, respectively. The black and red coloured faeces, collected during the growth and maintenance studies, respectively, were dried at room temperature for $48 \mathrm{~h}$, weighed, blended and stored at $-10{ }^{\circ} \mathrm{C}$ until analysed.. The total urine collected (days 23 - 29) was treated with $0.09 \mathrm{~N}$ HCL to avoid 
microflora growth. The respective faecal and urinary samples were pooled together and stored at $-10{ }^{\circ} \mathrm{C}$, until analyzed. The rats were sacrificed under ether anesthesia on day 29, and relevant internal organs harvested and weighed.

\subsection{Statistical analysis}

Statistical analysis was performed using IBM SPSS $^{\circledR}$ software package (version 16). Data was assessed for normality and homogeneity using the Shapiro-Wilk test. Following a positive normality test, a one-way analysis of variance was performed to separate the means with significant differences determined at $95 \%$ confidence interval. Results were expressed as means of six determinations \pm standard deviations.

\section{Results and Discussion}

\subsection{Proximate Composition}

The results of proximate composition of $R$. communis seeds (Table 2) showed that the URC crude protein, fat and crude fibre contents were significantly higher $(p<0.05)$ when compared with the BRC and FRC samples. However, processing by boiling and fermentation increased the carbohydrate contents by more than $100 \%(\mathrm{p}<0.05)$ in relation to the unprocessed samples. The decrease in the protein content of $R$. communis following processing (boiling and fermentation) might be due to denaturing and subsequent loss of its non-protein nitrogen (NPN) in the water. Heating by boiling is known to denature protein. Fermentation also creates a viable environment for microbial proteolytic enzymes to initiate the breakdown of proteins into component free amino acids. The increased free amino acids released leach into the water used in the process, which is eventually discarded. The crude protein composition of $R$. communis $(32.25 \%$ ), when compared with other conventional edible oil seed such as breadfruit (18.27\%) [10] and bambara groundnut $(23.41 \%)$ [11], is much higher. This high protein content of Ricinus communis seed positions it as a potential source for protein in diet formulations. The high fat content of $R$. communis (URC) is expected as it is an oil seed that stores fat as source of energy. The reduction of the fat content by fermentation and boiling can be attributed to loss in cooking and fermentation water following enzymatic hydrolysisby microorganismsas well as heat denaturation. The increased activity of lipolytic enzymes is generally known to increase the quality of fats in food as more free fatty acids (short and medium- chain) are released. The availability of fatty acids lead to potentially improved flavour and palatability of products [12]. Additionally, the increase in carbohydrate content of fermented and boiled samples might be attributed to increased amylolytic enzyme activity and gelatinization by cooking. Boiling carbohydrate-rich food caused gelatinization of the carbohydrate granules to increase the surface thus, exposing them to enzyme attack. The crude fibre $(3.25 \pm 0.70 \%)$ and ash content $(2.78 \pm 0.33 \%)$, were also higher in the URC while the moisture content showed the highest value in the BRC $(4.49 \pm 0.50 \%)$.

Table 2. Proximate composition of $R$. communis seeds (\%).

\begin{tabular}{|c|c|c|c|}
\hline Measured parameters & URC $^{\mathbf{a}}$ & BRC $^{\mathrm{b}}$ & FRC $^{\mathbf{c}}$ \\
\hline Moisture & $3.45 \pm 0.50^{\mathrm{b}}$ & $4.49 \pm 0.50^{\mathrm{ac}}$ & $3.29 \pm 0.30^{\mathrm{b}}$ \\
\hline Ash & $2.78 \pm 0.33^{\mathrm{c}}$ & $2.25 \pm 0.27$ & $2.00 \pm 0.49^{\mathrm{a}}$ \\
\hline Fat & $37.70 \pm 0.80 b^{c}$ & $24.50 \pm 0.50^{\mathrm{ac}}$ & $21.01 \pm 1.00^{\mathrm{ab}}$ \\
\hline Crude protein & $32.25 \pm 0.30^{\mathrm{bc}}$ & $23.13 \pm 0.20^{\mathrm{ac}}$ & $20.37 \pm 0.60^{\mathrm{ab}}$ \\
\hline Crude fibre & $3.25 \pm 0.70^{\mathrm{bc}}$ & $1.65 \pm 0.30^{\mathrm{a}}$ & $0.85 \pm 0.20^{\mathrm{a}}$ \\
\hline Carbohydrate & $20.54 \pm 0.60^{\mathrm{bc}}$ & $43.98 \pm 0.20^{\mathrm{ac}}$ & $52.47 \pm 0.30^{\mathrm{ab}}$ \\
\hline
\end{tabular}

Values are means from six rats $\pm \mathrm{SD}$. Data on the same column with different superscript letters from the group are significantly different ( $\mathrm{p}<0.05$ ).

\subsection{Growth Study}

The results of the growth study (Table 3 ) indicates that all the growth parameters measured (feed intake, weight gain, $\mathrm{N}$ intake and protein efficiency ratio-PER) were higher in the group of rats fed casein diet (control) and significantly different $(\mathrm{p}<0.05)$ from those fed with the test diets $(\mathrm{FRC}+\mathrm{C}, \mathrm{BRC}$ and $\mathrm{FRC})$. Although the $\mathrm{FRC}+\mathrm{C}$ diet was consumed more than the BRC and FRC diets, the differences were observed to be non-significant. Moreover, all the rats in the test diet groups experienced a loss of weight because of low diet intake.

Feed intake is influenced by palatability, source of $\mathrm{N}$ and essential amino acid (EAA) profiles $[13,14]$. The higher feed intake, resulting in higher $\mathrm{N}$ intake in rats fed CAS diet can be attributed to a combination of these factors as casein has desirable essential amino acid profile. However, the lower feed intake by rats fed with the test diets suggests that boiling or fermentation did not produce acceptable flavour or improve the palatability of the diet to the taste of the test animals [15]. The low feed intake consequently, resulted in weight loss (negative weight values) in rats fed test diets. The protein efficiency ratio (PER) measures the effectiveness of a protein in promoting growth. It is the simplest method for evaluating protein quality, as it requires only an accurate measurement of dietary intake and weight gained by growing rats after 28days of consumption of standard quantity of protein [16]. The higher PER of rats fed CAS diet is a reflection of the feed intake and the weight gained which were influenced by the desirable EAA pattern of casein. The lower PER values for rats fed test diets than those fed CAS diet might be due to the low feed intake and weight gain. The higher weight and PER of FRC group of rats than those fed $\mathrm{BRC}$ and $\mathrm{FRC}+\mathrm{C}$ might be as a result of their high feed intake. 
Table 3. Growth of rats fed with different Ricinus communis seed based diets ( $g$ ).

\begin{tabular}{|c|c|c|c|c|}
\hline Measured Parameter & $\mathbf{C A S}^{\mathrm{a}}$ & $\mathrm{BRC}^{\mathrm{b}}$ & FRC $^{\mathrm{c}}$ & $F R C+C^{d}$ \\
\hline Feed intake $(\mathrm{g})$ & $236.50 \pm 14.30^{\text {bcd }}$ & $107.30 \pm 14.20^{\mathrm{a}}$ & $106.50 \pm 15.60^{\mathrm{a}}$ & $114.50 \pm 8.30^{\mathrm{a}}$ \\
\hline Weight gain (g) & $54.00 \pm 10.70^{\text {bcd }}$ & $-12.00 \pm 3.90^{\mathrm{a}}$ & $-5.50 \pm 1.50^{\mathrm{a}}$ & $-11.30 \pm 4.10^{\mathrm{a}}$ \\
\hline $\mathrm{N}$ intake $(\mathrm{g})$ & $19.90 \pm 1.20^{\mathrm{bcd}}$ & $4.90 \pm 0.60^{\mathrm{ad}}$ & $4.80 \pm 0.70^{\mathrm{ad}}$ & $6.40 \pm 0.50^{\mathrm{abc}}$ \\
\hline PER (cal) & $2.70 \pm 0.40^{\text {bcd }}$ & $-2.60 \pm 0.80^{\mathrm{a}}$ & $-1.20 \pm 0.50^{\mathrm{a}}$ & $-1.80 \pm 0.30^{\mathrm{a}}$ \\
\hline
\end{tabular}

Values are means from six rats \pm standard deviation. Data on the same column with different superscript letters from the group are significantly different $(\mathrm{p}<0.05)$.

\subsection{Nitrogen Balance Assessment}

During the 7-day nitrogen balance study, the results (Table 4) for the feed intake and weight gain followed similar trend as those of the growth study. The rats fed CAS diet had higher feed intake and gained more weight than those in the groups fed with test diets (BRC, FRC and $\mathrm{FRC}+\mathrm{C}$ ). However, the difference in feed intake was not significantly different $(p>0.05)$ except when compared with those fed BRC diets. Although the rats in the NFD group had the highest feed intake, they experienced a weight loss, which differed significantly $(\mathrm{p}<0.05)$ from those of the rats fed the test and CAS diets. This weight loss is expected, as their feed was deficient in $\mathrm{N}$ source (protein) which is essential for maintenance of body tissues.

The results of the protein quality indices (BV, NPU, and TD) estimated in this study revealed high values for both the CAS control group and the test diet groups. These values ranged from $85-99 \%(\mathrm{BV}), 81-97 \%$ (NPU), and $89-98 \%$ (TD). In all, the CAS diet group had the highest values. The biological value of a protein is a measure of how efficiently food protein absorbed from the gastrointestinal tract is utilised in synthesis of body tissue [16]. The similarity of biological value of rats fed CAS diet and those fed test diets suggest that the test diets provided a good pattern of EAA that can potentially be utilized for synthesis of tissue protein. Whitney and Rolfes reported that a protein with a BV of $70 \%$ or more can support growth and tissue maintenance as long as energy intake is adequate [17]. Thus, the high BV of test diets suggests that protein from these diets can support body growth and tissue maintenance. NPU is a measure of both digestibility and $\mathrm{BV}$ of the amino acid mixture absorbed from food [13]. The high net protein utilization value in rats fed the test diets, which are similar to those of CAS diet group, indicates that the test diets could provide adequate protein for tissue maintenance. Ene-Obong and Obizoba maintained that the net protein utilization is more of a practical magnitude than $\mathrm{BV}$ in protein quality evaluation [13]. This is because digestibility is an important and integrated part of the nutritive value of a dietary protein source. True digestibility, gives information on $\mathrm{N}$ intake absorbed by the body. Whitney and Rolfes observed that most protein is worthless to the body, if they are not digested and absorbed [17]. Overall, the high NPU values obtained for the test diets suggest that they contain desirable patterns of EAA. Also, fermentation produced better $\mathrm{N}$ balance indices than boiling because of extensive hydrolysis of proteins that release more free amino acids due to increased microflora enzyme activity- a commonly observed phenomenon.

Table 4. Nitrogen balance of rats fed different Ricinus communis Seed based diets.

\begin{tabular}{|c|c|c|c|c|c|}
\hline Measured Parameters & $\mathbf{C A S}^{\mathrm{a}}$ & BRC $^{\mathbf{b}}$ & FRC $^{\mathbf{c}}$ & $F R C+C^{d}$ & NFD $^{e}$ \\
\hline Feed intake $(\mathrm{g})$ & $36.25 \pm 10.00^{\text {be }}$ & $16.25 \pm 2.80^{\text {ae }}$ & $21.75 \pm 3.40^{\mathrm{e}}$ & $19.25 \pm 1.70^{\mathrm{e}}$ & $83.50 \pm 23.70^{\mathrm{abcd}}$ \\
\hline Weight gain (g) & $2.75 \pm 0.30^{\mathrm{e}}$ & $-1.00 \pm 0.30^{\mathrm{e}}$ & $0.75 \pm 0.10^{\mathrm{e}}$ & $-1.25 \pm 0.20^{\mathrm{e}}$ & $-14.50 \pm 2.00^{\mathrm{abcd}}$ \\
\hline Faecal N (g) & $0.27 \pm 0.03^{\mathrm{e}}$ & $0.30 \pm 0.03^{\mathrm{e}}$ & $0.29 \pm 0.01^{\mathrm{e}}$ & $0.31 \pm 0.01^{\mathrm{e}}$ & $0.22 \pm 0.02^{\mathrm{abcd}}$ \\
\hline Urinary N (g) & $0.04 \pm 0.023^{\mathrm{ce}}$ & $0.09 \pm 0.02^{\mathrm{ce}}$ & $0.15 \pm 0.02^{\text {abde }}$ & $0.09 \pm 0.01^{\mathrm{ce}}$ & $0.01 \pm 0.00^{\mathrm{abcd}}$ \\
\hline Consumed N (g) & $3.05 \pm 0.80^{\mathrm{bcd}}$ & $0.74 \pm 0.01^{\mathrm{a}}$ & $0.99 \pm 0.10^{\mathrm{a}}$ & $1.10 \pm 0.06^{\mathrm{a}}$ & \\
\hline Absorbed N (g) & $2.99 \pm 0.84^{\mathrm{bcd}}$ & $0.68 \pm 0.08^{\mathrm{a}}$ & $0.92 \pm 0.15^{\mathrm{a}}$ & $0.99 \pm 0.09^{\mathrm{a}}$ & \\
\hline Retained N (g) & $2.96 \pm 0.87^{\mathrm{bcd}}$ & $0.59 \pm 0.08^{\mathrm{a}}$ & $0.78 \pm 0.14^{\mathrm{a}}$ & $0.92 \pm 0.09^{\mathrm{a}}$ & \\
\hline BV $(\%)$ & $99.00 \pm 1.00^{\mathrm{bc}}$ & $89.00 \pm 9.00^{\mathrm{a}}$ & $85.00 \pm 6.00^{\mathrm{a}}$ & $93.00 \pm 2.00$ & \\
\hline NPU (\%) & $97.00 \pm 3.00 \mathrm{~b}^{\mathrm{cd}}$ & $81.00 \pm 8.00^{\mathrm{a}}$ & $84.00 \pm 6.00^{\mathrm{a}}$ & $85.00 \pm 2.00^{\mathrm{a}}$ & \\
\hline $\mathrm{TD}(\%)$ & $98.10 \pm 1.50^{\mathrm{bcd}}$ & $89.75 \pm 3.30^{\mathrm{a}}$ & $93.00 \pm 3.90^{\mathrm{a}}$ & $91.88 \pm 0.90^{\mathrm{a}}$ & \\
\hline
\end{tabular}

Values are means from six rats \pm standard deviation. Data on the same column with different superscript letters from the group are significantly different $(\mathrm{p}<0.05)$

\subsection{Organ Weight Assessment}

The weight of major organs (liver, heart, kidney, brain and lungs) assessed in this study showed that the CAS diet group

had significantly higher $(p<0.05)$ organ weights when compared to the test diet groups. Also, the rats fed fermented diets had higher lungs and brain weight which was significantly different from those fed boiled diets. Obizoba and Nnam observed that organ weights were influenced by body weight, food and $\mathrm{N}$ intake [18]. 
Table 5. Organ weight of rats fed various test diets and casein (g).

\begin{tabular}{lllll}
\hline Organ weights & CAS $^{\mathrm{a}}$ & BRC $^{\mathrm{b}}$ & FRC $^{\mathbf{c}}$ & FRC $^{\text {d }}$ \\
\hline Liver $(\mathrm{g})$ & $5.25 \pm 0.95^{\text {bcd }}$ & $3.00 \pm 0.81^{\mathrm{a}}$ & $3.50 \pm 0.58^{\mathrm{a}}$ & $3.25 \pm 0.50^{\mathrm{a}}$ \\
Kidney (g) & $1.11 \pm 0.04^{\text {bcd }}$ & $0.71 \pm 0.14^{\mathrm{a}}$ & $0.7 \pm 0.11^{\mathrm{a}}$ & $0.73 \pm 0.05^{\mathrm{a}}$ \\
Lungs (g) & $0.78 \pm 0.16^{\mathrm{bcd}}$ & $0.38 \pm 0.03^{\mathrm{ac}}$ & $0.55 \pm 0.15^{\mathrm{ab}}$ & $0.45 \pm 0.04^{\mathrm{a}}$ \\
Brain (g) & $1.29 \pm 0.11^{\mathrm{bc}}$ & $0.93 \pm 0.03^{\mathrm{a}}$ & $1.06 \pm 0.14^{\mathrm{a}}$ & $1.15 \pm 0.20$ \\
Heart (g) & $0.53 \pm 0.05^{\mathrm{bcd}}$ & $0.23 \pm 0.03^{\mathrm{ad}}$ & $0.23 \pm 0.03 \mathrm{a}$ & $0.23 \pm 0.03^{\mathrm{ab}}$ \\
\hline
\end{tabular}

Values are means from six rats \pm standard deviation. Data on the same column with different superscript letters from the group are significantly different $(\mathrm{p}<0.05)$.

\section{Conclusion}

$R$. communis seed is rich in protein and processing particularly by fermentation, enabled release of desirable amino acids that showed good protein quality indices. However, the diets formulated using the processed samples were poorly consumed as observed in the low feed intake values among rats fed test diets. This strongly suggests that further study needs to be done to develop better or additional treatments that will enhance the flavour of the diets and improve palatability. However, during maintenance period, the high BV, NPU and TD values indicates that the seeds N derived from the little feed consumed, were well utilized in rats for tissue maintenance. More than $80 \%$ of $\mathrm{N}$ consumed from test diets was absorbed and retained. The processing methods used in this work (boiling and fermentation) are beneficial and are of nutritional importance to populations that prefer natural enhancement of nutrients to enrichment.

\section{References}

[1] Nnakwe, N. (1995). The effect and causes of protein energy malnutrition in Nigeria children. Nutr Res., 15. 15; 785-794.

[2] Ekeanyanwu, R. C (2013). Evaluation of the crude protein and amino acid composition of Nigerian Monodora myristica (ehuru). Pak. J. Nutr. 12; 219-223.

[3] Onwuliri, V. A. Attah, I., and Nwankwo, J. O. (2004). Antinutritional Factors, essential and non essential fatty acids composition of Ugba (Pentaclethra macrophylla) seeds at different stages of processing and fermentation. J. Bio. Sci., 4: 671-675.

[4] Achi, O. K. (2005). Traditional fermented protein condiments in Nigeria. Afri. J. Biotech., 4: 1612-1621.

[5] Ezeokonkwo, C. A. (2005). Effect of roasting on nutrient composition of Terminalia catappa seed. Nig. J. Nutr. Sci., 26: 19-24.

[6] Baros, P. R., Haro, A., Munoz, J. and Martinez, J. M. E. (2004). Isolation of a natural mutant in castor with high oleic/low ricinoleic acid content in the Oil. Crop SciSoc Am., 44: 76-80.
[7] Reeves, P. G., Nielsen, F. G and Fahey, G. C. Jr (1993). AIN93 purified diets for laboratory rodents. Final report of American Institute of Nutrition ad hoc writing committee on the reformulation of the AIN-76A rodent diet. J. Nutr., 123: 1939-1951.

[8] AOAC,(1990). Official methods of analysis $\left(15^{\text {th }}\right.$ ed $)$. Association of Official Analytical Chemists, Arlington, Virginia, USA.

[9] Sosulski, F. W. and Imafidon, G. I. (1990) Amino Acid Composition and Nitrogen-to-Protein Conversion Factors for Animal and Plant Foods. Journal of Agricultural and Food Chemistry. 38; 1351-1356.

[10] Obasuyi, J. O. and Nwokoro, S. O (2006). Physical and chemical properties of bread fruit (Artocarpus altilis) seeds collected from three locations in Edo state, Nigeria. Pakistan Journal of Nutrition., 5: 212 -214.

[11] Obizoba, I. C (1986). Comparison of nutritive value of cereal -based diets supplemented with pulses. Nig. J. Nutr. Sci., 7: 113-118.

[12] Obizoba, I. C. and Atti, J. V. (1994). Evaluation of the effect of processing techniques on the nutrient and antinutrient contents of pearl millet (Pennisetumglaucum) seeds. Plant foods Hum. Nutr., 45: 23 -34.

[13] Ene-Obong, H. N and Obizoba, I. C (1995). Protein quality of some Nigeriantraditional diets based on African yambean (Sphenostylis stenocarpcarpa) and pigeon pea (Cajanus cajana). Pl Fds. Hum. Nutr., 48: 293-309.

[14] Obizoba, I. C (1990). The effects of varying sprouting periods on the nutritional quality of normal yellow corn (Zea mays). Plant fds. Hum. Nutr., 40: 73-81.

[15] Obizoba, I. C (1986). Composition of nutritive value of cereal-based diets supplemented with pulses. Nig. J. Nutr. Sci., 7: 113-118.

[16] Wardlaw, G. M. Hampl, J. S., Disilvestrol, R. A. (2004). Protein in: Perspectives in nutrition, $6^{\text {th }}$ ed. Mc Graw Hil Companies US pp. 225-252, 374.

[17] Whitney, E. N. and Rolfes, S. R. (1996). Understanding nutrition, $7^{\text {th }}$ ed, West Publishing Co. NY. Pp. 171-203.

[18] Obizoba, I. C and Nnam, G (1992). The effects of sprouting times on nutritive value of two varieties of African yam bean (Sphenostylis stenocarpa). Pl. Fd. Hum. Nutr., 42: 319-327. 